\title{
Chronic Pain Incidence After Elective and Emergency
}

\section{Caesarean Sections}

\section{Acil ve Elektif Sezaryen Sonrası Kronik Ağrı Sıkı̆̆ı}

\author{
Hakan Tapar $^{{ }^{*}}$, Serkan Dogru${ }^{1}$, Serkan Karaman ${ }^{1}$, Tugba Karaman ${ }^{1}$, Hatice Yilmaz Dogru ${ }^{2}$, \\ Mustafa Süren
}

${ }^{1}$ Tokat Gaz̧iosmanpaşa Üniversitesi Tip Fakültesi Anesteriyoloji ve Reanimasyon Anabilim Dalı, Tokat, Türkiye

${ }^{2}$ Tokat Gaziosmanpaşa Üniversitesi Tip Fakültesi Kadın Hastalılarn ve Doğum, Tokat, Türkiye

\begin{abstract}
Objective: Chronic pain is a common health problem that may be associated with surgery. Chronic pain can lead to psychosocial issues and a deterioration in the communication with other people. This study was aimed to investigate the frequency of chronic pain in patients who underwent both elective and emergency caesarean sections.

Material and Method: This study was a prospective study enrolled 85 patients. These patients had all undergone caesarean section procedures, and were divided into two groups whether underwent the type of the procedure as elective or emergency. The study comprised of two distinct six-month periods completed in one year. Patients' data were collected in the first six months, and the patients were called by phone in the second six-month period. The patients' chronic pain was evaluated with respect to whether the caesarean section was performed elective or emergency.

Results: Chronic pain was found in $14.5 \%$ of the patients underwent elective caesarean section and in $18.9 \%$ of the patients underwent emergency caesarean section. A statistically significant relationship was not shown between groups ( $\mathrm{p}=0.595 ; \mathrm{p}>0.05)$.

Conclusion: No difference is found between emergency or elective caesarean section patients according to chronic pain incidence.
\end{abstract}

Key Words: Caesarean section, chronic pain, elective, emergency

\section{Introduction}

Pain is defined as a sensory and emotional displeasing experience correlated with real or potential tissue damage. Acute pain is short-term pain caused by peripheral nerve damage. Chronic pain was defined by the International Association for the Study of Pain (IASP) in 1999 as a pain

\section{ÖZET}

Amaç: Kronik ağrı cerrahi ile ilişkili olabilen yaygın bir halk sağlığı problemidir. Kronik ağr1 psikolojik sorunlara ve diğer insanlarla iletişim bozukluğuna yol açabilir. Bu çalışma hem acil hemde elektif sezaryen sonrası kronik ağrı sıklı̆̆ını araştırmayı amaçladı.

Gereç ve Yöntem: Bu çalışma 85 hastayı analiz eden prospektif bir çalışmadır. Hastalar acil ve elektif sezaryen olan hastalar olarak iki gruba ayrıldı. Çalışma iki ayrı altı aylık periyodu içeren bir yıllık bir çalışmaydı. İlk altı ay hasta verileri topland1 ikinci alt1 ayda hastalar telefonla arandı. Hastaların kronik ağrısı acil veya elektif sezaryen olup olmamalarına göre değerlendirildi.

Bulgular: Elektif sezaryen hastalarının \%14,5'inde, acil sezaryen hastalarının \%18,9'unda kronik ağrı bulundu. Gruplar arasında istatiksel olarak anlamlı bir fark bulunmadi $(p=0,595 ; p>0,05)$.

Sonuç: Kronik ağrı sıklığına göre acil ve elektif sezaryen hastaları arasında herhangi bir fark bulunmadı.

Anahtar Kelimeler: Sezaryen, kronik ağrı, elektif, acil

persisting for more than three months after a surgical procedure (1).

In recent years, it has been observed that chronic pain is a common health problem and may be associated with surgery (2). Chronic pain can lead to a range of psychosocial issues, resulting in job loss, disability, an avoidance of domestic and social responsibilities, and a deterioration in the sufferer's communication with other people (3). 
Table 1. Demographic characteristics of the patients

\begin{tabular}{lccc}
\hline & Emergency & Elective & $\mathrm{p}$ \\
\hline Agea $($ years $)$ & $28.45 \pm 5.22$ & $27.96 \pm 5.23$ & 0.456 \\
Height $(\mathrm{m})$ & $1.62 \pm 0.06$ & $1.65 \pm 0.04$ & 0.380 \\
Weight $(\mathrm{kg})$ & $78.16 \pm 12.71$ & $77.28 \pm 13.08$ & 0.654 \\
BMI $\left(\mathrm{kg} / \mathrm{m}^{2}\right)$ & $29.84 \pm 4.71$ & $28.89 \pm 3.74$ & 0.512 \\
PCS & $23.97 \pm 10.34$ & $20.96 \pm 1072$ & 0.196 \\
\hline
\end{tabular}

BMI,Body mass index; PCS, Pain catastrophizing scale

aValues are given as mean \pm SD unless indicated otherwise

${ }^{\mathrm{b}}$ Calculated as weight in kilograms divided by the square of height in meters

Table 2. Characteristics of pain

\begin{tabular}{lccc}
\hline & Elective & Emergency & $\mathrm{p}$ \\
\hline Chronic pain & 7 & 7 & 0.595 \\
Burning & 2 & 3 & \\
Stinging & 4 & 2 & \\
Daily activities & & & \\
$\quad$ Never & 0 & 0 & \\
Sometimes & 1 & 1 & \\
Often & 0 & 0 & \\
Always & 0 & 0 & \\
Sleep disturbance & & & \\
Never & 0 & 0 & \\
Sometimes & 0 & 1 & \\
$\quad$ Often & 0 & 0 & \\
Always & 0 & 0 & \\
\hline
\end{tabular}

All procedures that are carried out during a surgical operation carry intrinsic risks for future chronic pain (4), chronic pain affecting a patient's everyday life has been observed following a caesarean section (C/S). Chronic pain after $\mathrm{C} / \mathrm{S}$ has been defined as a pain that is both not associated with menstrual pain and that lasts more than three months after the birth (1). Any surgical operation including $\mathrm{C} / \mathrm{S}$ is a trauma, and can result in ilioinguinal, iliohypogastric, and genitofemoral nerve damage. Such damage can give rise to chronic pain, causing paraesthesia and dysaesthesia in the patient (5). The rate of chronic pain in post-operative $\mathrm{C} / \mathrm{S}$ patients is estimated to be $6-18 \%$ (6).

The occurrence of post-operative chronic pain can be affected by psychosocial factors, genetic factors and acute post-operative pain intensity (7). The Pain Catastrophizing Scale (PCS), in which has a score between zero and 52, developed by Sullivan has been used to gauge acute post-operative pain (8). The PCS score can estimate the severity of a patient's pain, as well as the likelihood of disability and emotional disturbance occurring after tissue damage and trauma (9). In our literature search, we did not come across any publications exploring the relationship between PCS score and emergency versus elective $\mathrm{C} / \mathrm{S}$. In this study, we aimed to investigate this relationship, filling that gap in the existing literature. We used the PCS scoring with a Turkish validation performed by Suren (10).

In previous studies, a relationship was discovered between the psychological condition of patients and their post-operative chronic pain (2). As we hypothesized that patients undergoing elective $\mathrm{C} / \mathrm{S}$ would have lower anxiety levels than emergency $\mathrm{C} / \mathrm{S}$ patients, we aimed to investigate the effect of undergoing emergency or elective $\mathrm{C} / \mathrm{S}$ on the occurrence of chronic pain.

\section{Material and Method}

After obtaining Tokat Gaziosmanpasa University Clinical Research Ethics Committee approval (15KAEK-028) and registering with clinicaltrials.gov (Grant number: NCT02656264), patients who had C/S between May 2015 and May 2016 were 
Table 3. Chronic pain associated with anesthesia type

\begin{tabular}{lccc}
\hline \multicolumn{2}{c}{ Emergency } & Elective & $\mathrm{p}$ \\
\hline General anesthesia & $5 / 27$ & $4 / 20$ & 0.744 \\
Spinal anesthesia & $2 / 16$ & $3 / 22$ & 0.864 \\
\hline
\end{tabular}

invited to the study and divided into two groups: those who had C/S electively, and those who had $\mathrm{C} / \mathrm{S}$ as an emergency operation. Whether a patient underwent $\mathrm{C} / \mathrm{S}$ as an emergency or elective procedure was decided by the obstetrician. Patients were included based on the criteria that they were over 18 years of age and had no clinical contraindications to spinal blockade and general anaesthesia. Women with a history of chronic pain, previous $\mathrm{C} / \mathrm{S}$, regular post-operative analgesic use, and those who were unwilling to participate in the study or could not be reached by phone were excluded from the study.

After written informed consent was obtained, all the patients who had undergone $\mathrm{C} / \mathrm{S}$ operations either emergency or elective conditions were asked, by the anaesthesiologist, to fill out the PCS questionnaire. The patients were contacted by phone at least three months after the $\mathrm{C} / \mathrm{S}$ procedure by an anaesthesiologist who was blind to the study groups. If patients were not contactable after two phone calls at different times of the day, they were deemed lost to followup. The patients were asked questions such as whether they experienced burning, stinging, or tingling near the incision area, or whether they experienced pain that interrupted their sleep or prevented them from doing work. Patients who exhibited these symptoms were accepted as having chronic pain.

The data of the patients who had $\mathrm{C} / \mathrm{S}$ were collected in the first six months of the study. In the second six-month period, the patients who had C/S were called by phone and their pain reports were evaluated. Patients were contacted by telephone 3-4 months after their C/S operations. A total of 162 patients who had C/S as an emergency or elective procedure were included in the study.

Patients were informed of general and spinal anaesthesia. The type of anaesthesia to be administered was selected according to each patient's choice, unless a medical contraindication was present. In such cases, the anaesthesiologist decided the type of the anaesthesia to be applied. General anaesthesia induction was performed intravenously (iv) with $0.6 \mathrm{mg} / \mathrm{kg}$ rocuronium bromide and $2 \mathrm{mg} / \mathrm{kg}$ propofol, and a volatile anaesthetic sevoflurane $1 \mathrm{MAC}$ and 50\%/50\%
$\mathrm{O}_{2} /$ Air mixture was used in the maintenance of the anaesthesia. After clamping of the umbilical cord, $1 \mathrm{mcg} / \mathrm{kg}$ of fentanyl was administered intravenously to all patients. Spinal anaesthesia was administered by injecting $0.5 \% \quad 12.5 \mathrm{mg}$ intrathecal heavy bupivacaine and $100 \mu \mathrm{g}$ morphine with a $25 \mathrm{G}$ Quincke tip needle with the patient in a sitting position under sterile conditions. Paracetamol $10 \mathrm{mg} / \mathrm{kg}$ three times a day and tramadol hydrochloride $1 \mathrm{mg} / \mathrm{kg}$ three times a day used as routine analgesics in the postoperative period.

Assuming an incidence of $10 \%$ chronic pain presence among elective cesarean sections and $35 \%$ among emergency cesarean sections, with a two-sided type I error of 0.05 , and a power of $0.80 ; 86$ subjects were required to find a significant difference. At the end of the one-year period, information related to the patients was gathered and statistically analysed. Data analysis was performed with the IBM SPSS version 20.0 statistical package (Chicago, IL, USA). The normal distribution fitness of the data was assessed using the one-sample Kolmogorov-Smirnov test. Quantitative data were expressed as numbers and percentages, and quantitative data were expressed as the mean \pm standard deviation. The normally distributed continuous variables were tested using the Student t-test. In the comparison of the qualitative data, Yates' Continuity Correction test (Yates' fix Chi-square) was used. Meaningfulness (Polysemy) was evaluated at levels of $\mathrm{p}<0.01$ and $\mathrm{p}<0.05$.

\section{Results}

A total of patients underwent elective C/S while, were emergency. Only 85 of the patients were able to be contacted by telephone for follow up, 37 in the emergency C/S group and 48 in the elective $\mathrm{C} / \mathrm{S}$ group (Figure 1). The demographic information of the patients can be found in Table 1.

As Figure 2 shows, chronic pain was observed in $14.5 \%$ of the patients who had elective C/S ( $n=7)$ and in $18.9 \%$ of the patients who had emergency $\mathrm{C} / \mathrm{S}(\mathrm{n}=7)$. A statistically significant relationship was not found between the performance of emergency versus elective $\mathrm{C} / \mathrm{S}$ and the occurrence 
Excluded $(\mathrm{n}=59)$

Not meeting inclusion criteria ( $\mathrm{n}=14$ )

Refused to participate

( $\mathrm{n}=36$ )

Other reasons $(n=9)$

\section{Assessed for eligibility}

$(n=162)$

\section{Randomized ( $\mathrm{n}=103$ )}

ceived allocated

intervention $(\mathrm{n}=38)$

Did not receive allocated intervention $(n=6)$

(With patients were not contactable)

Number of emergency cesarean section $(n=44)$

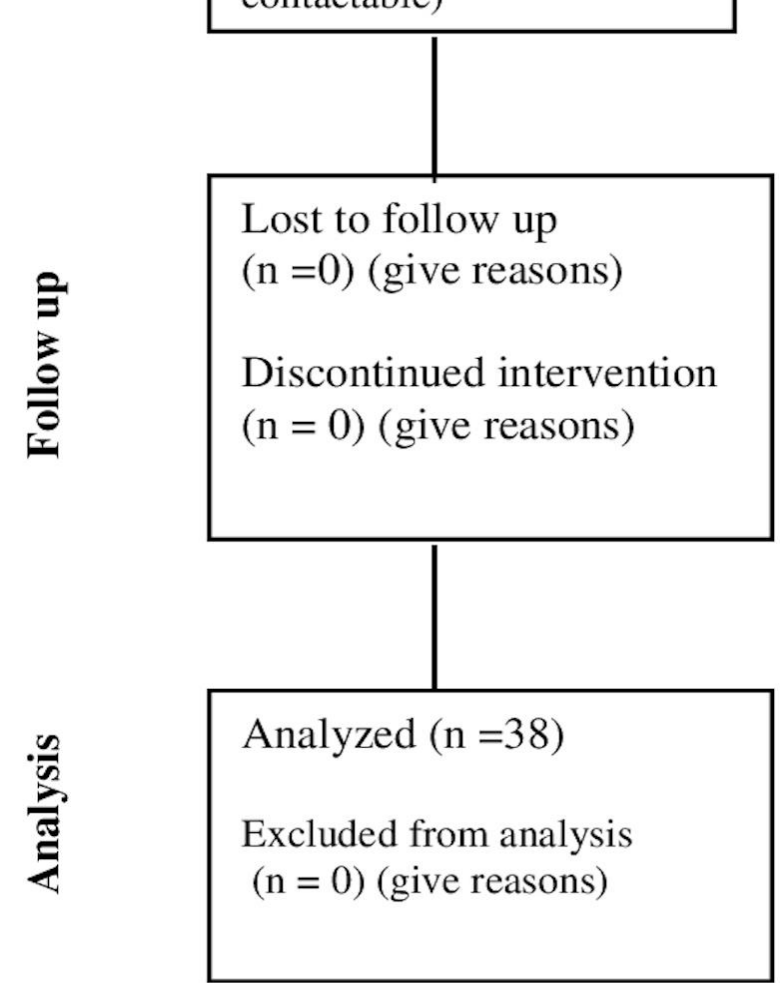

Number of elective

cesarean section $(\mathrm{n}=59)$

Received allocated

intervention $(n=47)$

Did not receive allocated intervention $(\mathrm{n}=12)$

(With patients were not contactable)

Lost to follow up

$(\mathrm{n}=0)$ (give reasons)

Discontinued intervention $(\mathrm{n}=0)$ (give reasons)

Fig. 1. Flow chart of cesarean sections patients

Analyzed $(n=47)$

Excluded from analysis $(\mathrm{n}=0)$ (give reasons) 


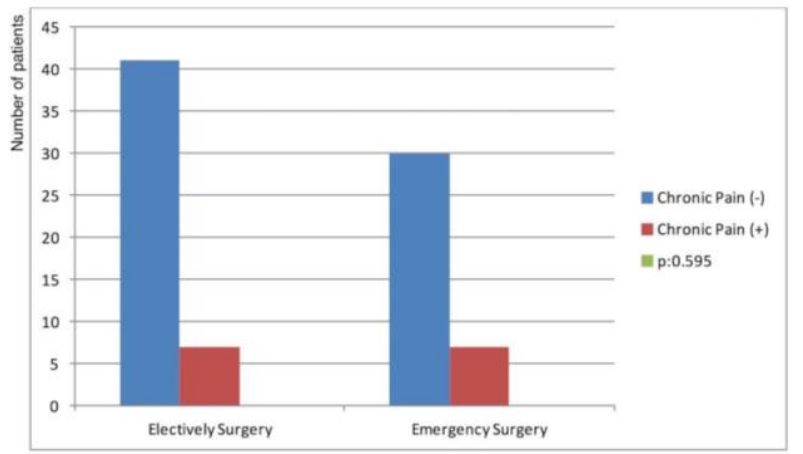

Fig. 2. The relationship between the type of anesthesia and chronic pain

of chronic pain $(\mathrm{p}=0.595)$ (Table 2$)$.

General anesthesia was performed 55\% $(n=47)$ of patients, where spinal anesthesia was $45 \%(n=48)$. As can be seen in Figure 3, chronic pain was seen in $19.1 \%$ of the $\mathrm{C} / \mathrm{S}$ patients to whom general anaesthesia was applied $(n=9)$ and in $13.1 \%$ of the $\mathrm{C} / \mathrm{S}$ patients to whom spinal anaesthesia was applied $\quad(n=5)$ A statistically significant relationship was not found between the method of anaesthesia applied and the occurrence of chronic pain $(\mathrm{p}=0.519)$.

$57 \% \quad(n=27)$ was urgent and $43 \%(n=20)$ was elective of patients received general anesthesia. Chronic pain was occurred $18.5 \% \quad(n=5)$ of patients with urgent operation under general anesthesia and $20 \%(n=4)$ of patients with elective operation under general anesthesia $(p=0.744)$ (Table 3).

$42 \% \quad(n=16)$ was urgent and 58\% (n=22) was elective of patients received spinal anesthesia. Chronic pain was found $12.5 \%(n=2)$ of patients with urgent operation under spinal anesthesia and $13.6 \%(n=3)$ of patients with elective operation under spinal anesthesia $(\mathrm{p}=0.864)$ (Table 3$)$.

The average PCS score of the patients who did not experience chronic pain was 19.14 ( \pm 10.59 ), while the average PCS score of the patients who experienced chronic pain was 22.89 ( \pm 10.48$)$. A statistically significant relationship was not found between the occurrence of chronic pain and the patients' PCS scores $(p=0.229)$.

While the PCS scores of the patients with elective $\mathrm{C} / \mathrm{S}$ averaged 20.96 ( \pm 10.72$)$, the PCS scores of the patients who had an emergency $\mathrm{C} / \mathrm{S}$ averaged 23.97 ( \pm 10.34$)$. There was no statistically significant difference between the PCS scores of the elective and emergency $C / S$ patients $(p=0.196)$ (Table 1).

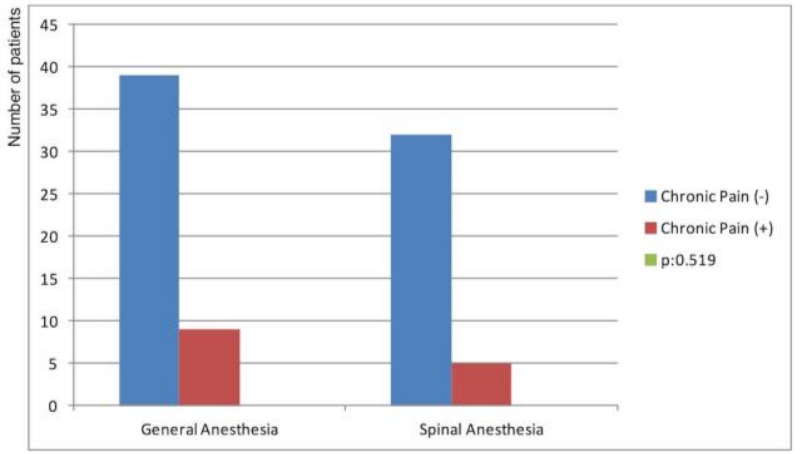

Fig. 3. The relationship between the nature of surgery and chronic pain

\section{Discussion}

In the present study, we found the frequency of chronic pain in the minimum three-month period after the $\mathrm{C} / \mathrm{S}$ to be $16.4 \%$. Jin et al. (11) demonstrated that chronic pain was observed as $18.3 \%, 11.3 \%$ and $6.8 \%$ in three, six and 12 months after caesarean section. In another study conducted by Nikolajsen et al. (12), which included $220 \mathrm{C} / \mathrm{S}$ patients, reported the frequency of chronic pain after $\mathrm{C} / \mathrm{S}$ to be $18.6 \%$ in the first three months, which dropped down to $12.3 \%$ ten months later. Despite these finding, Eisenach et al. (13) showed that the prevalence of chronic pain after caesarean section was $1.8 \%$ in six months and $0.3 \%$ in 12 months. However, the authors had a lack on follow-up in which they follow the patients six months and 12 months whose suffered from pain in two months and six months, respectively. In this context, these findings revealed that chronic pain frequency is diminished associated with time.

Kainu et al. (14) observed chronic pain in 18\% of the 83 elective $\mathrm{C} / \mathrm{S}$ patients and in $17 \%$ of the 133 non-elective $\mathrm{C} / \mathrm{S}$ patients, a difference which was not accepted as statistically meaningful. Liu et al. (15), who evaluated the frequency of chronic pain after C/S in 429 patients, did not find a significant difference between the frequency of chronic pain the performance of emergency versus elective $\mathrm{C} / \mathrm{S}$; this situation was explained by the fact that oxytocin has analgesic activity and plays a significant role in the pain modulation of the central nervous system. And also, this can explain the lower frequency of chronic pain following C/S procedures as compared to other surgical interventions (16). In the present study, we observed that undergoing $\mathrm{C} / \mathrm{S}$ operation as an emergency or elective procedure did not affect the frequency of chronic pain. We hypothesise that 
this situation can be explained by the equal amount of influence exerted by oxytocin in both the emergency and elective $\mathrm{C} / \mathrm{S}$ patients.

The frequency of chronic pain in $\mathrm{C} / \mathrm{S}$ patients who were operated on under spinal anaesthesia was found to be lower than the rate among those who were operated under general anaesthesia. This situation has been explained by the stronger blockade of central impulses in spinal anaesthesia (7). Contrary to the results of this study, Sprung et al. conducted a study in which the effects of general anaesthesia and spinal anaesthesia on chronic pain were compared in 89 hysterectomy patients in a 12-week period and found no difference between the groups (17). In the present study, a statistically significant difference was not found between the patient groups to which general or spinal anaesthesia was applied. This result can be explained by the fact that analgesia with a post-operative effect was provided to all the patients regardless of their method of anaesthesia. In this context, the efficient management of acute postoperative pain might decrease the frequency of chronic pain (18). A study conducted by Moriyama et al. (19) in 225 patients demonstrated that no difference was detected in postoperative $3^{\text {rd }}$ month chronic pain frequency between patients received general, epidural or spinal anesthesia. However, this study showed that additional $100 \mathrm{mcg}$ of morphine during spinal anesthesia was decreased the frequency of chronic pain.

Post-operative pain has been determined to be one of the most important predictors of chronic pain. One of the parameters used in estimating post-operative pain is PCS (20). Forsythe et al. (21) reported that PCS can be used to estimate chronic pain. There are also studies indicating that PCS is not effective in estimating post-operative chronic pain (22). Lautenbacher et al. (23) conducted a study in which the predictive mechanisms for post-operative chronic pain were investigated, gauging patients' pain intensity and pain disability over a three-month and a six-month period. They found that PCS was not an effective method to predict post-operative chronic pain. Grosen, in his study evaluated chronic pain after thoracic surgery, obtained similar results (24). In the present study, a relationship between PCS scores and chronic pain was not found. In addition, no difference was found between the PCS values of the patients who had $\mathrm{C} / \mathrm{S}$ as an emergency or an elective procedure.

This prospective study was constrained by several limitations. Psychological factors play a major role in the development of post-operative pain. Methods evaluating psychological factors, such as anxiety and depression scores, were not conducted. Further studies investigating these psychological factors would be useful. Although the number of patients was statistically sufficient, this number could be higher to improve the generalizability of the outcomes.

In conclusion, chronic pain might be a challenging problem after $\mathrm{C} / \mathrm{S}$. We did not find a significant difference between the frequency of chronic pain in patients who delivered with $\mathrm{C} / \mathrm{S}$ under emergency or elective conditions. We also did not find any difference between the chronic pain frequencies of the $\mathrm{C} / \mathrm{S}$ patients to whom general anaesthesia or spinal anaesthesia were applied.

\section{References}

1. Landau R, Bollag L, Ortner C. Chronic pain after childbirth. International Journal of Obstetric Anesthesia 2013; 22(2): 133-145.

2. Macrae WA. Chronic post-surgical pain: 10 years on. Br J Anaesth 2008; 101(1): 77-86.

3. Hamberg K, Johansson E, Lindgren G, Westman G. The impact of marital relationship on the rehabilitation process in a group of women with longterm musculoskeletal disorders. Scand J Soc Med 1997; 25(1): 17-25.

4. Perkins FM, Kehlet H. Chronic pain as an outcome of surgery. A review of predictive factors. Anesthesiology 2000; 93(4): 11231133.

5. Klaassen Z, Marshall E, Tubbs RS, Louis RG, Wartmann CT, Loukas M. Anatomy of the ilioinguinal and iliohypogastric nerves with observations of their spinal nerve contributions. Clinical Anatomy 2011; 24(4): 454-461.

6. Martin JA, Hamilton BE, Sutton PD, Ventura SJ, Mathews TJ, Osterman MJ. Births: final data for 2008. Natl Vital Stat Rep 2010; 59(1): 1-72.

7. Brandsborg B, Nikolajsen L, Hansen CT, Kehlet H, Jensen TS. Risk factors for chronic pain after hysterectomy: a nationwide questionnaire and database study. Anesthesiology 2007; 106(5): 1003-1012.

8. Sullivan MJ, Bishop SR, Pivik J. The Pain Catastrophizing Scale: Development and validation. Psychol Assess 1995; 7(4): 524-532.

9. Marić A, Banožić A, Ćosić A, Kraljevic S, Sapunar D, Puljak L. Validation of the Croatian pain catastrophizing scale through a study on the influence of medical education 
on pain catastrophizing. Period Biol 2011; 113(2): 171-175.

10. Suren M, Okan I, Gökbakan AM, Kaya Z, Erkorkmaz U, Arici S, et al. Factors associated with the pain catastrophizing scale and validation in a sample of the Turkish population. Turk J Med Sci 2014; 44(1): 104108.

11. Jin J, Peng L, Chen Q, Zhang D, Ren L, Qin $P$, et al. Prevalence and risk factors for chronic pain following cesarean section. BMC Anesthesiol 2016; 16(1): 99.

12. Nikolajsen L, Sorensen HC, Jensen TS, Kehlet H. Chronic pain following caesarean section. Acta Anaesthesiol Scand 2004; 48(1): 111-116.

13. Eisenach JC, Pan P, Smiley RM, Lavand'homme P, Landau R, Houle TT. Resolution of pain after childbirth. Anesthesiology 2013; 118(1): 143-151.

14. Kainu JP, Sarvela J, Tiippana E, Halmesmaki E, Korttila KT. Persistent pain after caesarean section and vaginal birth: a cohort study. Int J Obstet Anesth 2010; 19(1): 4-9.

15. Liu TT, Raju A, Boesel T, Cyna AM, Tan SG. Chronic pain after caesarean delivery: an Australian cohort. Anaesth Intensive Care 2013; 41(4): 496-500.

16. Kehlet H, Jensen TS, Woolf CJ. Persistent postsurgical pain: risk factors and prevention. Lancet 2006; 367(9522): 1618-1625.

17. Sprung J, Sanders MS, Warner ME, Gebhart JB, Stanhpoe CR, Jankowski CJ, et al. Pain relief and functional status after vaginal hysterectomy: intrathecal versus general anesthesia. Can J Anaesth 2006; 53(7): 690700.

18. Lavand'homme P. Postcesarean analgesia: effective strategies and association with chronic pain. Curr Opin Anaesthesiol 2006; 19(3): 244-248.

19. Moriyama K, Ohashi Y, Motoyasu A, Ando T, Moriyama K, Yorozu T. Intrathecal Administration of Morphine Decreases Persistent Pain after Cesarean Section: A Prospective Observational Study. PLoS One 2016: 11; e0155114.

20. George SZ, Wallace MR, Wright TW, Moser MW, Greenfield WH 3rd, Sack BK, et al. Evidence for a biopsychosocial influence on shoulder pain: pain catastrophizing and catechol-O-methyltransferase (COMT) diplotype predict clinical pain ratings. Pain 2008; 136(1-2): 53-61.

21. Forsythe ME, Dunbar MJ, Hennigar AW, Sullivan MJ, Gross M. Prospective relation between catastrophizing and residual pain following knee arthroplasty:two-year followup. Pain Res Manag 2008; 13(4): 335-341.

22. Gramke HF, de Rijke JM, Van Kleef M, Kesseis AG, Peters ML, Sommer M, et al. Predictive factors of postoperative pain after day-case surgery. Clin J Pain 2009; 25(6): 455460.

23. Lautenbacher S, Huber C, Schöfer D, Kunz M, Parthum A, Weber PG, et al. Attentional and emotional mechanisms related to pain as predictors of chronic postoperative pain: a comparison with other psychological and physiological predictors. Pain 2010; 151(3): 722-731.

24. Grosen K, Vase L, Pilegaard HK, Jensen MP, Drewes AM. Conditioned pain modulation and situational pain catastrophizing as preoperative predictors of pain following chest wall surgery: a prospective observational cohort study. PLoS One 2014; 9: e90185. 